E International

\title{
Permanent Observatories as Tools for Ex-Post Assessment
}

The French case study

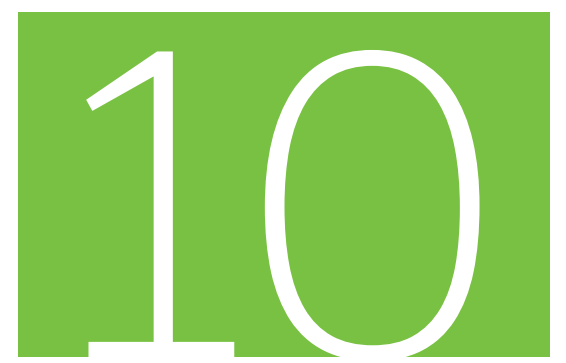

Discussion Paper 2014 • 10

Alain Bonnafous

Laboratoire d'Économie des Transports (LET), Lyon, France 


\title{
Permanent Observatories as Tools for Ex-Post Assessment: The French case study
}

\author{
Discussion Paper No. 2014-10
}

\section{Prepared for the Roundtable on}

Ex-post Assessment of Transport Investments and Policy Interventions (15-16 September 2014, OECD, Paris)

\author{
Alain BONNAFOUS \\ Professor Emeritus, Lyon University \\ Laboratoire d'Économie des Transports (LET), Lyon, France
}




\section{THE INTERNATIONAL TRANSPORT FORUM}

The International Transport Forum at the OECD is an intergovernmental organisation with 54 member countries. It acts as a strategic think-tank, with the objective of helping shape the transport policy agenda on a global level and ensuring that it contributes to economic growth, environmental protection, social inclusion and the preservation of human life and well-being. The International Transport Forum organises an annual summit of Ministers along with leading representatives from industry, civil society and academia.

The International Transport Forum was created under a Declaration issued by the Council of Ministers of the ECMT (European Conference of Ministers of Transport) at its Ministerial Session in May 2006 under the legal authority of the Protocol of the ECMT, signed in Brussels on 17 October 1953, and legal instruments of the OECD.

The Members of the Forum are: Albania, Armenia, Australia, Austria, Azerbaijan, Belarus, Belgium, Bosnia and Herzegovina, Bulgaria, Canada, Chile, the People's Republic of China, Croatia, the Czech Republic, Denmark, Estonia, Finland, France, the Former Yugoslav Republic of Macedonia, Georgia, Germany, Greece, Hungary, Iceland, India, Ireland, Italy, Japan, Korea, Latvia, Liechtenstein, Lithuania, Luxembourg, Malta, Mexico, the Republic of Moldova, Montenegro, the Netherlands, New Zealand, Norway, Poland, Portugal, Romania, the Russian Federation, Serbia, the Slovak Republic, Slovenia, Spain, Sweden, Switzerland, Turkey, Ukraine, the United Kingdom and the United States.

The International Transport Forum's Research Centre gathers statistics and conducts co-operative research programmes addressing all modes of transport. Its findings are widely disseminated and support policymaking in member countries as well as contributing to the annual Summit.

\section{Discussion Papers}

The International Transport Forum's Discussion Paper Series makes economic research, commissioned or carried out at its Research Centre, available to researchers and practitioners. The aim is to contribute to the understanding of the transport sector and to provide inputs to transport policy design.

ITF Discussion Papers should not be reported as representing the official views of the ITF or of its member countries. The opinions expressed and arguments employed are those of the authors.

Discussion Papers describe preliminary results or research in progress by the author(s) and are published to stimulate discussion on a broad range of issues on which the ITF works. Comments on Discussion Papers are welcomed, and may be sent to: International Transport Forum/OECD, 2 rue André-Pascal, 75775 Paris Cedex 16, France.

For further information on the Discussion Papers and other JTRC activities, please email: itf.contact@oecd.org

The Discussion Papers can be downloaded from: www.internationaltransportforum.org/jtrc/DiscussionPapers/jtrcpapers.html

The International Transport Forum's website is at: www.internationaltransportforum.org 


\section{Table of Contents}

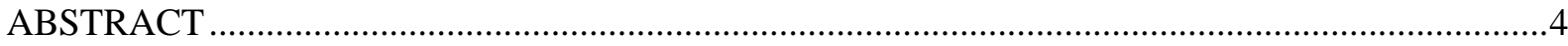

1. INTRODUCTION

2. FRENCH EXPERIENCE WITH "LOTI AUDITS" ..............................................................6

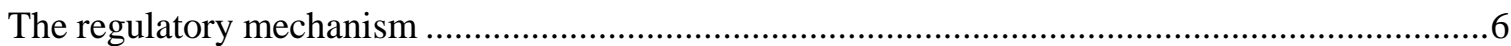

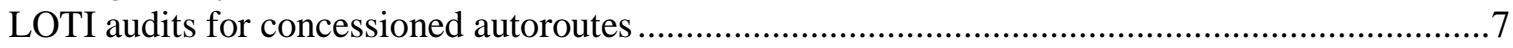

LOTI audits of the new high-speed rail lines (lignes à grande vitesse, LGV) …............................

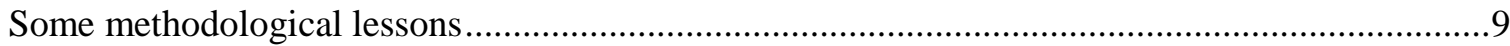

3. FROM EX-POST EVALUATIONS TO THE NOTION OF A PERMANENT

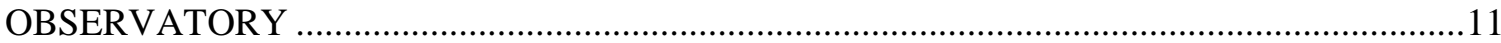

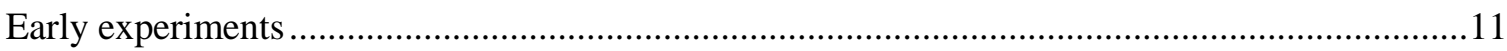

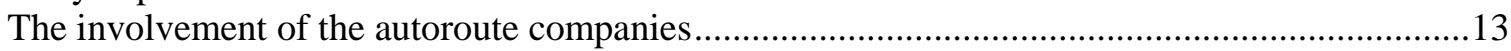

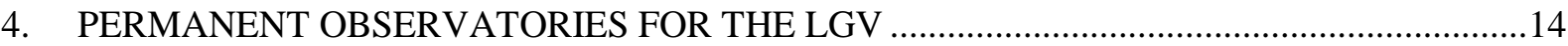

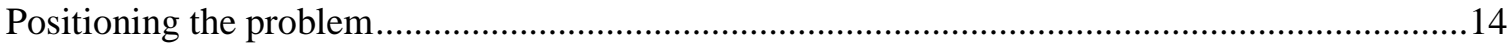

The socioeconomic observatory for the LGV LISEA (2012-2027) ............................................15

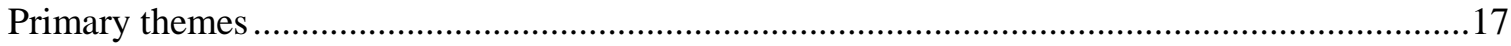

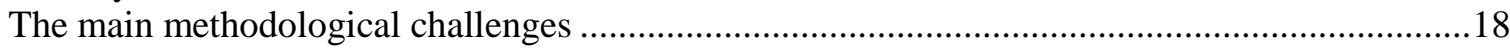

5. CONCLUSION: ADDRESSING THE CHALLENGES OF COMPLEX AND

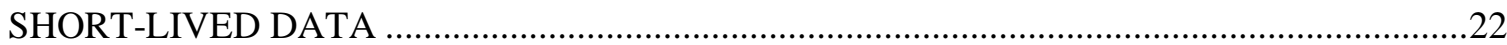

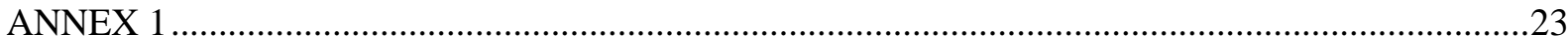

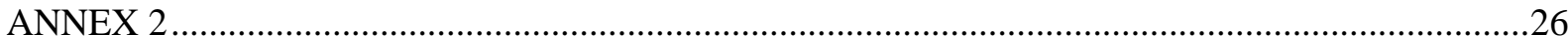

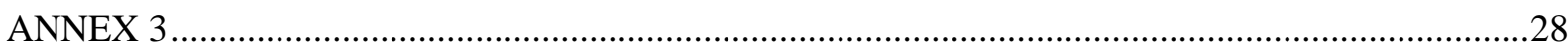

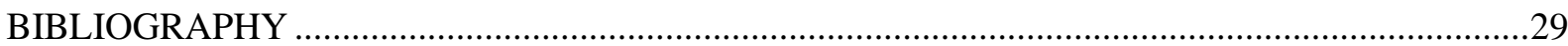




\begin{abstract}
In France, the obligation to conduct an ex-post assessment is relatively recent (1982) but it has in fact revealed some methodological problems that flow from the retrospective nature of the exercise. This report shows that some of those difficulties can be overcome through the establishment of permanent observatories. It presents examples of such observatories, with a particular focus on motorway ("autoroute", or "freeway" in North American usage) investments. A particular case is then investigated, concerning the socioeconomic observatory on the effects of the Sud-Europe-Atlantique [South-Europe-Atlantic] high-speed train line that is now under construction. This major project ( $€ 7.8$ billion) has been let under a concession. The concession contract calls for the establishment of an observatory that also covers the construction period and is to remain in operation for 10 years after the line comes into service, or until 2027. Besides an overall presentation of the mechanism, the report deals in particular with the metrological precautions that must be taken in order to monitor the multimodal offer of transport for the areas concerned. One of the key issues here, in fact, is to explain the discrepancies between forecast and projected and actual traffic, an explanation that may be more complete than in the ex-post evaluation procedure.
\end{abstract}

\title{
1. Introduction
}

The decision to make public funds available for studies or research subsequent to the coming on stream of new infrastructure in Europe was first made in the 1970s. At that time, the primary concern was not to conduct a socioeconomic assessment in the strict sense, but rather to identify the effects that had not been taken into account in the standard evaluation procedure then in force, and that were referred to as "indirect" or "structuring" effects of infrastructure investments. The European Conference of Ministers of Transport (ECMT) anticipated (ECMT, 1969) and then supported these initiatives (ECMT, 1975).

Clearly, then, the first question was how to measure the impacts not caught in the socioeconomic calculation, i.e. those that might reveal further advantages from the investment. This concern not to underestimate advantages was an important consideration at that time. At the end of the 1960s, Europe had a series of uncompleted motorway networks that were built as an emergency response to relieve major traffic bottlenecks, and the resulting reduction in congestion implied very high returns in socioeconomic terms. Because the highway segments needed to complete that priority network presented more modest rates of return, it was legitimate for the sponsoring administrations to seek out advantages for the projects that might have been overlooked, if only to be able to select the "best" projects. 
Attention therefore turned to drawing lessons from concrete cases and studying regional trends in areas where transport conditions could be significantly improved through large-scale infrastructure investments. A number of ex-post studies were thus conducted on a number of major projects (ECMT, 1969 and 1975), for example the Autostrada del Sole motorway between Milan and Naples, inaugurated in 1964, the M62 motorway in the United Kingdom (Lancashire-Yorkshire Motorway), the Severn Bridge linking Wales and England, and the A7 Autoroute along the Rhône Valley south of Lyon.

A scientific comparison of the results of the studies yielded some lessons on which there was fairly broad consensus. First, each case study presented so many specific features that this in itself constituted a problem. Thus, a motorway linking Lombardy, one of Europe's richest regions, with the Mezzogiorno, which contained some of the poorest areas, raised the question of regional rebalancing; the A7 autoroute (Autoroute du Soleil) in France or the M62 in the United Kingdom, which served areas of roughly equivalent development, posed the problem of "transit" effects and, in the second case especially, the question of effects on the urban hierarchy; the Severn Bridge linked two regions so closely as to raise the issue of the merger of market areas.

Secondly, all the studies pointed to the lack of systematic impacts from these major projects and the difficulty, when looking at the effects ex-post, of specifying the role of the new infrastructure vis-à-vis other factors. For example, although statistics might reveal a certain concentration of activities near motorway interchanges, could this be interpreted as an effect of infrastructure or as representing the attractiveness of urban centres located, as a rule, near to interchanges?

The studies from that time ultimately concluded that if regional development apparently induced by these investments were observed it could reasonably be assumed that this represented a displacement of activity towards a better-served region, rather than any net creation of value. Consequently, what was needed was not so much to evaluate some regional enrichment as to learn to use infrastructure investments as territorial development tools in the sense of regional rebalancing (Bonnafous, 1979).

This of course tended to shift the initial problem from poorly-estimated value creation to another, no less difficult problem, which was to understand the mechanisms of regional development and the specific role that the availability of transportation could play. It was quite natural, then, to see some initiatives to apply a methodological approach to this problem. In France, these efforts led to the establishment of permanent observatories of socioeconomic developments in regions served by new infrastructure.

These initiatives were launched at the end of the 1970s. Shortly afterwards, in the 1980s, legislation was adopted requiring an ex-post evaluation of major projects (or of significant technological innovations), an evaluation known as the Bilan LOTI, the "LOTI audit" or balance sheet - LOTI stands for "Loi d'orientation des transports intérieurs", "Domestic transport planning law" - of which we shall present the principles and selected results in the second section. As we shall see through some examples of such audits, a number of lessons can be drawn from these experiments.

At the present time, the usefulness of these LOTI audit reports is generally admitted, although their authors have themselves identified the limitations of such retrospective investigations. In section 3 , we shall identify what may have been the first initiatives to create permanent observatories in France, which had to do with a problem complementary to that of the LOTI audits and which contained information of a different nature. These initiatives were initially conducted by academic circles, but were then supported by the autoroute operators. A presentation of some of them allows us to appreciate their methodological contribution. Recognition of these contributions naturally sparked the idea of taking a more ambitious and long-term approach that would combine the advantages of 
permanent observation and of ex-post evaluation. The case study of the socioeconomic observatory of the LGV Sud-Europe-Atlantique, which is unique as it is supposed to function until 2027, will be presented in section 4 with some details on the particular methodological difficulties revealed by its implementation.

\section{French Experience with "LOTI Audits"}

For a long time it seemed to be the practice in France that the file on a major investment was effectively closed once the infrastructure entered into service. Officially, the notion of ex-post evaluation was introduced only in the 1980s.

\section{The regulatory mechanism}

The term "LOTI audit" reflects the fact that these ex-post evaluations of major transportation projects became compulsory with passage of the "Domestic transport planning law" of December 1982. In 2010, that obligation was reiterated and spelled out in a new "transport code" which updated all the legislative provisions organising the transportation sector in France.

First, there is an obligation for the sponsoring authority or project owner (maitre d'ouvrage) to prepare an ex-ante evaluation and an ex-post assessment of major infrastructure projects that are publicly financed, if the project cost exceeds $€ 83$ million. The project owner is responsible for conducting the assessment and has 3 to 5 years after entry into service to produce it.

This ex-post balance sheet is published, notably on the project owner's website, for example the site of the RFF (Réseau Ferré de France) for railway projects. It gives rise to an official avis [opinion] from the reviewing authority, which includes the inspectors general of the ministry responsible for transport. This opinion is also published at the website and in two newspapers of national circulation.

The purposes of these ex-post reports are explicit. They are:

- to inform the public about the status of the operation, and in particular about the discrepancies between forecast and actual outcomes, and to reveal the causes of those discrepancies;

- to render accounts for the use of public funds by evaluating ex-post the economic, social and environmental efficiency of the investments made; and

- to provide feedback for improving the methods of ex-ante project evaluation.

This is, then, a very conventional approach that consists essentially of producing a critical analysis of the forecasts and assessments made prior to the decision to proceed with the project. This can cause a problem within the sponsoring institution, which will have been responsible for these forecasts and achievements and will then be asked to render a critical assessment of them. To prevent the exercise from being self-serving, different agencies are involved. Thus, within the RSS, the LOTI audit for 
railway projects is entrusted to the "audit and risks division" which is functionally independent of the units responsible for ex-ante evaluations. Lastly, this report is enriched by the opinions of the independent body identified earlier.

The lessons to be drawn from these exercises must be distinguished according to the nature of the investment. The complete list of official audits available is shown in Annex 1. Given the purpose of this report, we shall focus only on the two main investments involving toll motorways (autoroutes under concession) and high-speed rail lines.

\section{LOTI audits for concessioned autoroutes}

The authors of the LOTI audit reports and the official opinions place particular stress on the quality of traffic forecasts. Thus, the official site presenting these opinions specifies that the purpose is to "compare the forecasts on which the previous choices were based and the actual outcomes of those choices". To summarise the main outcomes, we shall look at the discrepancies between the forecast and actual economic internal rates of return or EIRR. Table 1 below shows the most important autoroutes covered by LOTI audits and indicates the apparent reasons for the main discrepancies between planned and actual outcomes.

Generally speaking, traffic forecasts tend to underestimate rather than overestimate future traffic flows. This reflects the fact that the uncertainties inherent in forecasts have to do primarily with the allocation of traffic across the highways network, and more particularly between toll and toll-free routes. As the intermodal dimension is of little importance, we may conclude that traffic allocation represents the most consistent modelling technique.

The disappointing EIRRs can generally be laid to the fact that costs are underestimated to such an extent that they cannot be offset by higher-than-expected traffic volumes. This is a complex problem. If we examine the cost estimates in detail, the discrepancies can indeed be glaring for some projects. In the case of the A57 autoroute, for example, right-of-way acquisition costs exceeded forecasts by $80 \%$, and safety equipment costs by $108 \%$. On the other hand, civil works costs - a very significant item for investments in a hilly region - came in $30 \%$ below estimate. It must be recalled, though, that this project was prepared more than 25 years ago, and the LOTI reports noted that with the current system of competitive tendering, in force in France since 2001, the discrepancies are more reasonable.

It will be noted, however, that these ex-post audits say little about the impact on the local area, a reticence that contrasts with the importance of these indirect effects in the considerations preceding the decision. The key point relates to the local developments that these new investments are supposed to bring with them. The audits are generally confined to comparing forecast and actual employment effects generated by the construction phase and, after entry into service, by operation of the autoroute and its service plazas. 
Table 1. Ex-ante/ex-post comparisons of LOTI balance sheets: economic returns for the main concessioned motorways

\begin{tabular}{|c|c|c|}
\hline Motorway Segment & $\begin{array}{l}\text { Ex-ante/ex-post } \\
\text { discrepancies }\end{array}$ & Principal explanation \\
\hline $\begin{array}{l}\text { A49 } \\
\text { Grenoble Valence } \\
\text { (Opened in 1992) }\end{array}$ & $\begin{array}{l}\text { Initial forecast EIRR: } 14 \% \\
\text { Initial observed EIRR: } 19 \%\end{array}$ & $\begin{array}{l}\text { Costs closely controlled and } \\
\text { traffic flows higher than } \\
\text { forecast. }\end{array}$ \\
\hline $\begin{array}{l}\text { A57 } \\
\text { Cuers-Le Cannet des Maures } \\
\text { (Opened in 1992) }\end{array}$ & $\begin{array}{l}\text { Forecast EIRR: } 20 \% \\
\text { Ex-post EIRR: } 14.8 \%\end{array}$ & $\begin{array}{l}\text { Traffic flows higher than } \\
\text { forecast, but very great cost } \\
\text { overruns. }\end{array}$ \\
\hline $\begin{array}{l}\text { A54 } \\
\text { St Martin de Crau-Salon de } \\
\text { Provence } \\
\text { (Opened in 1996) }\end{array}$ & $\begin{array}{l}\text { Initial forecast EIRR: } 30 \% \\
\text { Initial observed EIRR: } 15.4 \%\end{array}$ & $\begin{array}{l}\text { Costs controlled but traffic } \\
\text { flows far below forecasts. }\end{array}$ \\
\hline $\begin{array}{l}\text { A837 } \\
\text { Saintes-Rochefort } \\
\text { (Opened in 1997) }\end{array}$ & $\begin{array}{l}\text { Initial forecast EIRR: } 13 \% \\
\text { Initial observed EIRR: } 5 \%\end{array}$ & $\begin{array}{l}\text { Traffic flows far below } \\
\text { forecasts. }\end{array}$ \\
\hline $\begin{array}{l}\text { A83 } \\
\text { Nantes-Niort } \\
\text { (Opened in 2001) }\end{array}$ & $\begin{array}{l}\text { Ex-post EIRR: } 15 \% \\
\text { Greater than forecast EIRR not } \\
\text { specified in the audit report }\end{array}$ & $\begin{array}{l}\text { Cost overruns more than } \\
\text { offset by higher-than- } \\
\text { expected traffic flow. }\end{array}$ \\
\hline $\begin{array}{l}\text { A20 } \\
\text { Brive-Montauban } \\
\text { (Opened in 2003) }\end{array}$ & $\begin{array}{l}\text { Forecast EIRR: } 8 \% \\
\text { Ex-post EIRR: } 8 \%\end{array}$ & $\begin{array}{l}\text { Cost overruns offset by } \\
\text { higher-than-expected traffic } \\
\text { flow }\end{array}$ \\
\hline $\begin{array}{l}\text { A28 } \\
\text { Alençon-Tours } \\
\text { (Opened in 2005) }\end{array}$ & $\begin{array}{l}\text { Forecast EIRR: } 15.5 \% \\
\text { Ex-post EIRR: } 10 \%\end{array}$ & Cost overruns \\
\hline
\end{tabular}

Source: Bilans LOTI, cf. Annex 1.

\section{LOTI audits of the new high-speed rail lines (lignes à grande vitesse, LGV)}

It is not necessary here to select the most important projects in order to draw some lessons from these LOTI audits, as there have been only six, all of them large-scale and costly. The main discrepancies between forecasts and outcomes are summarised in the table below for the comparative EIRRs, as well as for the FIRRs, which by law must be calculated ex-ante for LGV projects.

The differentials between forecast and actual IRR are the result in part of poorly controlled costs, and also of traffic volumes that have fallen short of expectations. The most frequent cost overruns relate to infrastructure, generally stemming from supplementary investments or tightness in the public works market. They also relate to rolling stock purchase and operating costs, which seem inexplicably unpredictable. 
Table 2. Ex-ante/ex-post comparisons of LOTI audits: Economic rates of return for high-speed rail lines

\begin{tabular}{|c|c|c|c|}
\hline \multirow[t]{2}{*}{ LGV Project } & \multicolumn{2}{|c|}{ Ex-ante/ex-post differentials } & \multirow[t]{2}{*}{ Principal explanation } \\
\hline & EIRR & FIRR & \\
\hline $\begin{array}{l}\text { LGV Atlantique } \\
\text { (Opened in 1992) }\end{array}$ & $\begin{array}{l}\text { Expected: } \\
23.6 \% \\
\text { Ex-post: } 14 \%\end{array}$ & $\begin{array}{l}\text { Expected: } \\
12.9 \% \\
\text { Ex-post: } 8,5 \%\end{array}$ & $\begin{array}{l}\text { Traffic and revenues higher } \\
\text { than forecast, but heavy cost } \\
\text { overruns (more than 20\%). }\end{array}$ \\
\hline $\begin{array}{l}\text { LGV Nord-Europe } \\
\text { (Opened in 1993) } \\
\text { (extended to Belgium in } \\
1996 \text { ) }\end{array}$ & $\begin{array}{l}\text { Expected: } \\
20.3 \% \\
\text { Ex-post: } 5 \%\end{array}$ & $\begin{array}{l}\text { Expected: } \\
12.9 \% \\
\text { Ex-post: } 2.9 \%\end{array}$ & $\begin{array}{l}\text { Traffic below forecasts; } \\
\text { revenues close to forecast } \\
\text { thanks to increased fares, but } \\
20 \% \text { infrastructure cost overrun. }\end{array}$ \\
\hline $\begin{array}{l}\text { Interconnexion Ile-de- } \\
\text { France } \\
\text { (Opened in 1994) }\end{array}$ & $\begin{array}{l}\text { Expected: } \\
14.1 \% \\
\text { Ex-post: } 6.9 \%\end{array}$ & $\begin{array}{l}\text { Expected: } \\
22.3 \% \\
\text { Ex-post: } 15 \%\end{array}$ & $\begin{array}{l}\text { Traffic increases below forecast } \\
\text { and overruns on rolling stock } \\
\text { and operating costs. }\end{array}$ \\
\hline $\begin{array}{l}\text { LGV Rhône-Alpes } \\
\text { (Opened in 1994) }\end{array}$ & $\begin{array}{l}\text { Expected: } 14 \% \\
\text { Ex-post: } 10.6 \%\end{array}$ & $\begin{array}{l}\text { Expected: } 9 \% \\
\text { Ex-post: } 6.1 \%\end{array}$ & $\begin{array}{l}\text { Benchmark traffic below } \\
\text { forecast and overruns on rolling } \\
\text { stock and operating costs. }\end{array}$ \\
\hline $\begin{array}{l}\text { LGV Méditerranée } \\
\text { (Opened in 2001) }\end{array}$ & $\begin{array}{l}\text { Expected: } 11 \% \\
\text { Ex-post: } 8.1 \%\end{array}$ & $\begin{array}{l}\text { Expected: } 8 \% \\
\text { Ex-post: } 4.1 \%\end{array}$ & $\begin{array}{l}\text { Benchmark traffic close to } \\
\text { forecast but lower traffic } \\
\text { increases and overruns on } \\
\text { rolling stock and operating } \\
\text { costs. }\end{array}$ \\
\hline $\begin{array}{l}\text { LGV Est } \\
\text { (Opened in 2007) }\end{array}$ & $\begin{array}{l}\text { Expected: } \\
8.5 \% \\
\text { Ex-post: } 4.2 \%\end{array}$ & $\begin{array}{l}\text { Expected: } 7.2 \% \\
\text { Ex-post: } 5.9 \%\end{array}$ & $\begin{array}{l}\text { Cost overruns }(+20.2 \%) \\
\text { partially offset by higher-than- } \\
\text { expected traffic }\end{array}$ \\
\hline
\end{tabular}

Source: Bilans LOTI, cf. Annex 1.

With respect to traffic, it is clearly important to identify the causes of error, especially those relating to traffic increases beyond the benchmark . For LGVs, traffic forecasting is more difficult than for autoroutes, where the problem is primarily one of allocating traffic across the highway network. In the case of high-speed rail lines, the task is to project the traffic induced by a significant movement in service, as well as a modal shift that is harder to control. While the forecasts were quite accurate for the LGV Atlantique, they were overestimated for the LGV Nord-Europe. There, the LOTI audit report offers no lessons as to the mistake that was made in calculating the modal shift from highway to rail for short runs such as Paris-Lille. As to air competition, it reflects the steep but unanticipated fare cuts on Paris-London and Paris-Brussels flights. In the first case, there was a mistake in model specification, while in the second case there was an erroneous hypothesis concerning an exogenous parameter.

\section{Some methodological lessons}

The lessons that can be drawn from these LOTI audits are of general application, and can be summarised in two points. First, there is a real problem with cost control, resulting in glaringly excessive overruns, particularly for LGV rolling stock and operating costs. The methodological response is to strengthen the risk assessments by taking cost uncertainties more thoroughly into 
account. This has been done for the ambitious Tours-Bordeaux LGV project ( $€ 7.8$ billion), discussed below.

Second, the analysis of traffic forecasting errors generally involves choosing between the main explanations: a mistaken benchmark estimate, most often due to faulty macroeconomic assumptions, errors in modal distribution, often due to mistaken assumptions about the competitive context, and errors in traffic allocation or modal distribution resulting from faulty modelling.

Erroneous assumptions lead to the same recommendation as costing errors, and call for development of a risk analysis methodology. Model specification errors are a much more intractable problem, as the ex-post evaluation is done several years after entry into service and does not always have the statistical data needed for rigorous distinction between exogenous assumption errors and specification errors.

Taking intermodal competition as an example, it is nearly impossible to reconstruct an airfare history given the multitude of different fares resulting from the airlines' "yield management" approach. In this case, only the operators will have a chronological series for the different airfare levels and their weighting, and commercial secrecy prevents them from disclosing these data (a point that applies as well to rail operators). The only methodological response to this problem is to collect real-time data, which brings us to the need for a permanent observatory.

Similarly, beyond traffic considerations and the elements of economic and financial return, the LOTI audits have attempted to provide some information on the economic impacts of projects. The idea is to compare what could be observed following entry into service with what had been promised in the project's initial plan. Two extensive chapters are typically devoted to these issues in the documentation that is used for the public hearing prior to the official "declaration of public utility". One of them addresses the economic activities surrounding the construction phase itself, and then the operation of the facility, and they are assessed in terms of their direct job creation effect. The other looks at the anticipated indirect economic effects of all kinds, which are generally highlighted in the public hearing documents. In both cases, the idea is to ensure positive fallout for the regions traversed by the infrastructure in order to counter frequently vocal opposition, including the NIMBY ("not in my backyard!") phenomenon.

With respect to the promised "direct employment creation", this is not generally a focus of observation. For example, for the six LGV projects listed in Table 2, the public hearing document mentioned a specific number of anticipated new jobs in each case. Only one of the six LOTI audits contains an ex-post estimate. For the LGV Atlantique, a specific study cited in the LOTI audit estimated actual employment at the work site at 21,600 job-years, compared to the forecast of 33400 , and 11000 job-years for the rolling stock, versus the projected 20000 . In defence of the LOTI report authors, it should be noted that retrospective reconstruction of such effects is dauntingly complex in the absence of real-time data.

As to the indirect economic effects, which may be highly variable as we shall see in the following sections, the public hearing documents are often very optimistic as to the expected fallout for regional development. The LOTI audits are more discreet on what is observed: the LGV North was supposed to attract new development to Lille, but the balance between activity relocating to Lille from Paris and movements in the opposite direction is "very difficult to establish", according to the official audit report. The LGV Rhône-Alpes was supposed to encourage air-rail trade-offs at Saint-Exupéry Airport, but in fact only $0.5 \%$ of air traffic has been affected. The LGV Méditerranée was supposed to promote specific developments around the new train stations at Valence, Avignon and Aix-en-Provence but the LOTI audit revealed nothing significant. The LGV Est was supposed to reinforce the role of 
Strasbourg as a European capital, but the LOTI audit contents itself with quoting the Chamber of Commerce of Strasbourg to the effect that the city "now ranks in the class of big cities for the TGV."

In fact, for direct and indirect effects alike, these retrospective assessments have the greatest difficulty in establishing the statistics or the facts needed to identify them. Thus, each analysis is based on data which at best require a great deal of reconstitution and, at worst, do not exist at all. The LOTI audits are thus reduced to hunting around for elements in specific studies that may have been undertaken at the initiative of local or national agencies. The methodological response to this problem lies in the implementation of permanent observatories.

\section{From Ex-post Evaluations to the Notion of a Permanent Observatory}

It is not by accident that some operators, in particular autoroute concessionaires, have gradually been drawn toward permanent observation arrangements. These initiatives have generally recognised that they were following the example of a series of academic studies.

\section{Early experiments}

The first French experiment with permanent observatories was purely academic. It involved the implementation of a system called SPOT (Système Permanent d'Observation sur le Triangle LyonChambéry-Grenoble).

From the methodological viewpoint, this operation was largely inspired by the studies that will be mentioned here and that were conducted by the same research team looking at the indirect effects of the A7 autoroute in the Rhône Valley. That highway was put into service between 1962 and 1968. The retrospective study thus benefited from surveys that happened to be conducted in those same years. Moreover, an ex-post survey in 1975 provided valuable information on the demographic and economic situation seven years after the last autoroute segments were brought into service. Many other reports were also assembled and analysed for the periods before and after 1968.

The vast statistical bases thus constituted were used to establish an ex-ante typology of municipal dynamics between 1962 and 1968 and an ex-post typology of those dynamics between 1968 and 1975 . The methodology was based on comparing these two typologies in order to identify significant shifts that might reveal the effects of the autoroute (Plassard, 1977). Thus, of the more than 400 communes involved, some saw changes in their typical dynamics, probably influenced by their relative proximity or distance from an autoroute interchange. A field survey was then undertaken to validate or discard one or other interpretation of the role of the autoroute in bringing about these changes.

The field survey, though, was limited to some 30 communes designated by these statistical treatments. In-depth interviews served to validate and flesh out some of the results. For example, as the autoroute ran along the left bank of the Rhone the right bank fell into something of an economic depression, as borne out by local residents who felt that "the other bank was too attractive". Another example is the revival of economic activity along the old highway (the famous Nationale 7), which was relieved of much of its congestion with the opening of the A7, and where managers of newly established 
businesses confirmed that this was a key factor in their choice of location. However, the field studies, which were conducted five or six years after the A7 opened, sometimes faced difficulties in gaining access to information: some players could no longer be reached, others reconstituted economic performances that were in total contradiction with the statistical record, some significant information was not conserved, etc.

These difficulties led the researchers to undertake a comparative investigation that could be conducted in real time so as to catch information before it disappeared. In support of an ambitious programme of the National Scientific Research Centre (CNRS) on "the observation of social change", the LET (Laboratoire d'économie des transports, the "Transportation Economics Laboratory") was selected to institute, on an experimental basis, a permanent observatory for the geographic area served by the new autoroute linkages in the Rhône-Alpes region. As it happened, this research programme was launched at the same time as the opening of the A43 autoroute Lyon-Bourgoin-Chamberry (completed in 1974) and the section of the A48 linking Bourgoin and Grenoble (completed in 1975).

This SPOT mechanism enabled close monitoring (Gérardin et al., 1981) of a sufficient number of indicators to reveal demographic or economic changes in the 245 communes that make up the triangle under observation. For example, they allowed the following themes to be addressed:

- Industrial activity and its transformations were monitored by a monthly survey of high- or medium-voltage electricity consumption in each commune. This indicator was particularly useful for revealing local trends in industrial output, either up or down. In the case of business closures or relocations, it was generally possible to identify important trends several months before they actually occurred, and in this way to conduct in-depth interviews with the players concerned.

- Municipal budgets were systematically recorded, making it possible to identify those communes that were purchasing new equipment or that were experiencing particular growth, in terms of housing or business activities.

- Building permits and property transfers were also recorded, as a supplement to this coverage.

- A set of 21 communes comprising the Ville Nouvelle de l'Isle d'Abeau was subjected to especially close monitoring, entailing a number of field studies, and this revealed the relative failure to shorten home-work commuting distances, which the design of the new city was supposed to promote.

From a methodological viewpoint, the SPOT mechanism proved to be a powerful explanatory tool. For example, this area had historically been characterised by a large number of textile industries scattered across small towns and villages. It so happens that the opening of the autoroute coincided with a profound crisis in the French textile industry, which was already facing stiff competition from emerging countries. If a retrospective study had been conducted at the end of that time, the effects of the autoroute would have been found to be offset by employment losses in the hinterland and barely sustained activity near the interchanges. Field studies conducted immediately and after abrupt changes appeared in certain types of industrial output made it possible to sort out the local effects of the textile crisis from the effects on the attractiveness of activity zones located near the autoroute.

More generally, this experience showed that permanent observation could be more useful than ex-post studies, and that it could be an effective response to fleeting phenomena, the disappearance of data, and the loss of stakeholder memory. 


\section{The involvement of the autoroute companies}

Based on its initial results, the Rhône-Alpes autoroute company (AREA) was induced to cooperate with this first experiment, and subsequently to provide financial assistance. Its interest in such an observatory went beyond the elements determining the project's economic profitability, and other autoroute companies came to share this view.

In France during the 1980s and 1990s, the decision-making process regarding major capital projects changed significantly to make greater room for debate and consensus building. As a result, there was a demand for specific knowledge: one of the main themes systematically addressed in the context of these participatory procedures had to do, of course, with territorial development, which became an essential element for a project's social acceptability. As a result, autoroute observatories were launched by the Ministry of Equipment, by its research unit on highway and autoroute techniques (SETRA), and by three autoroute concession companies, Autoroutes Paris-Rhin-Rhône (APRR), Autoroutes du sud de la France (ASF), and the Société française du tunnel routier du Fréjus (SFTRF).

The ten or so observatories that were launched met with varying success, as these evaluation mechanisms were not covered by any regulatory requirements. We shall mention here only the two main experiments, which benefited from the solid support of APRR. The observatory for the A71 autoroute (Bourges/Clermont-Ferrand) was in operation from 1986 to 1997, in partnership with the CERAMAC laboratory of the Universite de Clermont-Ferrand; the observatory for the A39 (Dole/Bourg-en-Bresse) operated between 1993 and 2004, in partnership with the ThéMA laboratory of the Université de Franche-Comté.

The report from the A71 Observatory identified three "series of major facts", relating to territorial interaction (Varlet and Jamot, 2002):

- The A71 and the more southerly route via the A75 and the southeast, make the Massif Central a "potential transit space". The more recent arrival of the A9 has resulted in a major autoroute crossroads at Clermont-Ferrand, which has reinforced this transit function.

- The autoroute link has sparked a "temporary imbalance in local economic systems through the emergence of exogenous as well as endogenous dynamics". The external influences can be seen in the establishment of a hotel chain beside the A71, by the expansion of shopping centres, and by a tendency for businesses installed in the hinterland without links to transport networks to move closer to autoroute interchanges. There has also been a boom in the establishment of secondary residences.

- Growth in nodes located near to the autoroute has encouraged a degree of urban sprawl as businesses located in denser urban centres made the short move to areas closer to the interchanges, which were deemed more functional.

The observatory for the A39 started work at the outset of the construction phase in 1992, and continued operations until 2004, or six years after the last segment of the autoroute entered service. This was, then, the first opportunity for an up-close examination of the direct effects on the local economy and employment, and it produced some very specific results for the construction phase (procurement from local producers, employee spending and consumption habits, local taxes paid, etc.); on operation of the autoroute (jobs created by the concessionaire and subcontractors, local taxes, etc.); and on the reorganisation of traffic (the shift of long-distance traffic from the national route to the autoroute, increased traffic near the interchanges, etc.). 
Two series of observations were conducted to pinpoint the indirect effects as well:

- One set of effects related to the autoroute itself, which gave rise to three types of developments: adaptations of the spaces physically impacted by the autoroute (regrouping of farmlands and modernisation of feeder roads from the interchanges into the surrounding territory), the economic and local development effects of accessibility and proximity to the autoroute (activity zones, preparation of development projects and inter-municipal cooperation), and promotion of the territory (installation of high-quality service areas).

- The other set concerned the use and usefulness of the infrastructure for the broader territory: as far as mobility practices and business logistics are concerned, the adaptations observed were modest.

The most significant results related to the concerns of the public authorities (and the autoroute companies), described earlier. In a public debate still marked by the NIMBY phenomenon, it is important to be able to identify the typical effects cited by those interviewed, especially in the case of the last observatory mentioned. Finally, we should note that the A39 observatory provided considerable input to the LOTI audit, supplying information that an ordinary ex-post balance sheet would never have been able to reconstruct.

We may note that, for autoroute investments, the permanent observatory methodology has been well tested, with accumulated experience that allows us to delimit thoroughly the object of the observation, whether this relates to the direct effects that the observatories have found to be important, or the indirect effects that are still highly dependent on the potential of the areas affected and on exogenous variables.

The situation is clearly different in the case of investments in high-speed rail links, where the "gravitational pull" of the interchanges is not an issue.

\section{Permanent Observatories for the LGV}

There is no inherent reason why the methods of ex-ante evaluation or ex-post audit cannot be applied to these investments as well. However, expanding the approach to include the socioeconomic effects of an $L G V$ raises a problem that is quite different from that of the autoroute case.

\section{Positioning the problem}

The first difference has to do with the mode of transport itself. When it comes to traffic and advantages for users, autoroute projects typically involve the redistribution of traffic from the old highway and, in contrast to the time savings offered by a new project, there is generally very little in the way of a modal shift. In the case of high-speed rail lines, modal transfers are naturally much more important, whether this involves a shift away from highway travel for short and medium distances or a shift away from air travel for longer distances. 
In each case, the relative difficulty can be readily appreciated. In the first case, it is enough to monitor autoroute traffic, something that is easy to do as most autoroutes operate under the "closed toll" system , and then to supplement this with regular vehicle counts on alternative routes, in order to have a sufficient time series for comparing forecast and actual traffic and for explaining the discrepancies. In the case of a new high-speed rail line, we must make a distinction between traffic diverted from highways and airlines and rail traffic induced by the improvement. This presupposes a degree of consistency among different statistical sources, and usually specific "passenger" surveys as well. It also assumes that the characteristics of the different modes available are captured in detail, including speed of travel, schedules and fares, in order to analyse forecasting errors.

The infrastructure itself and its related services have characteristics quite different from those of the autoroute, starting with the fundamental difference between a train station and a highway interchange. Although some suburban or rural stations have been built on the new lines, TGVs generally serve central stations, and a considerable portion of traffic is city-centre to city-centre. Autoroute interchanges, on the contrary, are generally located far from city centres.

As a result, the spatial diffusion is quite different: the autoroute interchange serves exclusively to ensure highway accessibility to city centres and rural areas, while the train station distributes traffic into urban areas via complementary modes: private automobile, foot traffic, public transit, taxi, or transfer by train to secondary stations.

We may conclude, then, that the spatial effects of an LGV will not be the same as those of an autoroute. At the risk of oversimplifying, we may summarize the differences between their respective "structuring effects" by noting that autoroutes produced primarily "transit effects" (effets de traversé, i.e. the impact on the areas through which they pass) while an LGV is likely to induce "pole" or "hub" effects (effets de pôle", i.e. the impact on areas at each end of the line), which may lead to a rebalancing of urban hierarchies (Bonnafous, 1980).

All of these differences can be appreciated by presenting the case of the socioeconomic observatory for the LGV Sud-Europe-Atlantique.

\section{The socioeconomic observatory for the LGV LISEA (2012-2027)}

The LGV from Tours to Bordeaux is now under construction and will come into service in 2017. Its $300 \mathrm{~km}$ of new line will complete the high-speed link from Paris to Bordeaux, cutting the travel time from three hours to two hours and five minutes. The new line has been let under concession by the Réseau Ferré de France to the LISEA company, a subsidiary of VINCI. The concession contract calls for serving the stations on the existing rail network via a system of connections between the LGV and the existing line: 10 connections are planned, representing $40 \mathrm{~km}$ of supplementary rail segments. The main cities served by these connections will be Poitiers and Angoulême (see maps in Annex 2 and travel times table in Annex 3).

This is an innovative project in terms of financing, as it uses the concession system to limit public borrowing. The overall cost of EUR 7.8 billion will be financed as follows:

- $\quad$ EUR 3.8 billion from LISEA, of which $20 \%$ in equity and the remainder borrowed;

- EUR 1 billion from RFF, based on a loan backed by the expected additional revenues from expanding traffic on the existing network, and hence fare revenues; 
- $\quad$ EUR 3 billion in subsidies, half of which will come from the State and half from the local governments concerned.

It may be noted that this last item of financing involved negotiations between five regional councils, 19 departments and 33 "communautés de communes" or metropolitan areas. Each of these partners had an interest in the layout of the new line, either because of the TGV (high-speed train) services it would offer them or because of subsequent extensions of the line. This aspect is obviously important for the content and the geographic scope of the observatory, especially as the financial contributions were justified by the project's expected economic effects.

Given the scope of the project, presented as the biggest concession project in Europe, the prospect of an LOTI audit by 2020 or so, and the expectations of the local governments co-financing the project, the responsible authority (Réseau Ferré de France) introduced a clause in the concession contract obliging the concessionaire to establish and finance a socioeconomic observatory for the effects of the new line, known as OSE-LISEA.

This contractual provision thereby ensures permanent financing for the observatory, which is to function for ten years after the line comes into service, i.e. until 2027 at least. This is a considerable methodological advance, for the socioeconomic effects of a structural nature will only appear with the passage of time. In nearly all the studies cited above, the authors have stressed that the observation time after entry into service has been too short.

Moreover, the fact that the observatory was put in place when the works had barely begun helped to prevent any loss of information on the "construction phase effects", as confirmed by the first results on this topic (Fouqueray, 2013). It also served to identify, early on, the potential questions and expectations of some of the key players (Manceau, 2012).

The objectives of the OSE-LISEA are spelled out in the concession contract. Thus, it is to "evaluate the direct and indirect effects of the LGV SEA on mobility, the local economy, and territorial development. The output of the Observatory must:

- be useful to local stakeholders for integrating the LGV into their territory to best advantage;

- provide input to national stock-taking and debate on the effects of high-speed rail lines and be useful for forward planning."

The resulting organisation of the observatory involves units of the State as well as the local partners. It is managed by a technical and administrative team within LISEA, assisted by a scientific committee of academics to help in preparing and evaluating progress with the work programme. The State units participate in a monitoring committee that validates this programme, while the local partners (elected officials, local government units, chambers of commerce) are consulted by two regional commissions (North and South) set up to address the particular expectations of the regional geographic hubs, namely Aquitaine/Midi-Pyrénées and Poitou-Charentes/Centre. 


\section{Primary themes}

The scientific committee proposed an initial work programme (Manceau, 2013) calling for observations and analyses based on six themes:

1. "Construction phase" effects. Experience with autoroute projects (Bérion et al., 2007) has shown the usefulness of putting a mechanism in place promptly to monitor the local effects of the construction phase and to identify the geographic distribution of the effects on the production system. This is obviously an issue of pressing local political interest, as revealed at the public presentations of the initial results.

2. Transportation availability and traffic volumes. This is obviously the most important theme for the detailed design and usefulness of future LOTI audits. The required information can be broken down into three categories:

- User-friendly time schedules. Given the heavy competition from airlines on the longer routes, the schedules must be surveyed for both modes and for the train stations and airports involved. For rail service, the schedule also constitutes a demand for "track time" slots from RFF and LISEA, an important consideration for the financial profitability of the project.

- $\quad$ Fares. While information on time schedules can be stored or even reconstituted, the situation is quite different with fares, as they are governed by "yield management" both for air and for TGV services. As we shall see in the next section, information on this point is typically short-lived.

- Passenger traffic. Paradoxically, statistics on autoroute or air traffic are more accessible than those for rail traffic, where the historic operator insists on commercial confidentiality. Fortunately, a recent regulation will make most of these data available, although with a one-year lag. It will likely be necessary to conduct passenger surveys before and after entry into service.

3. "Station effects". Numerous observations (Bazin et al., 2009, Richer et al., 2009) have found very significant urban developments in the immediate vicinity of the TGV stations. Urban developments should in fact be monitored closely, starting several years before entry into service, given the expectations of stakeholders.

4. Metropolitan and territorial dynamics. This theme arises whenever an LGV makes significant changes to travel distances and times between urban areas. An ex-ante/ex-post study of the very first TGV project in France produced important results on this theme (Buisson et al., 1986). Spatial relationships are necessarily part of an urban hierarchy that involves a regional capital, Bordeaux, of recognised dynamism, but also Paris, the economic clout of which is based on centuries of centralisation. It is important, then, to observe as closely as possible the transformations in this hierarchy, which obviously involves the medium-sized cities.

5. Effects on tourism. There is a wealth of statistical information on this theme in France, relating both to accommodation capacities and visitor numbers. The OSE-LISEA will however be limited to areas likely to be strongly affected by differences in supply. The work programme will therefore focus in particular on urban tourism. 
6. Strategies of stakeholders and organisations. The first contacts with local stakeholders who spontaneously declared their interest in the observatory's work programme revealed a very optimistic outlook. This sometimes seems to be based on an overestimate of the new availability of transportation, but it may also lead to real initiatives that should be inventoried and analysed, for the "branding effect" of TGV service has been highlighted in nearly all the studies.

\section{The main methodological challenges}

This work programme has been introduced progressively and has already revealed some methodological problems, some of which are inherent to the very notion of a permanent observatory. The most important issues relate to two principal difficulties: one is the need to synthesise complex information into a limited number of indicators, the relevance of which can pose a problem; the other has to do with the fleeting nature of information, which can disappear if it is not compiled promptly. We shall confine ourselves here to two illustrations of these problems, both of which relate to supply monitoring.

As to the relevance of the indicators, the example selected concerns the problem of delivering a synthetic description of time schedule changes. As things stand now, the local political authorities seem to attach great importance to the number of daily train runs. In fact, however, the question is not whether there will be "at least six TGVs per day in each direction", as one mayor demanded during the negotiations on public financing, but rather whether the schedules and their related services will make it easier to get to certain destinations, starting with Paris.

Work was therefore undertaken to compile a composite body of information, by its nature complex, representing hundreds of departure and arrival times and to make sense of that information. To illustrate these initial efforts (Joho, 2013) we take the notion of "available time at destination", which is determined on the basis of the proposed schedules, but under the constraint of a departure time ("not before $X$ o'clock") and return time ("not after $X$ o'clock"). Figure 1 below illustrates this concept using the example of a one-day round trip between Bordeaux and Paris.

On this three-dimensional graph, the outward-bound train's departure time is shown on axis 1 and the arrival time of the return train is shown on axis 2 . The length of time available at destination can then be determined from the vertical axis (axis 3). This value corresponds to the co-ordinate of a point that is at the intersection of the curve representing the consumption of time on the outbound train and the curve representing the consumption of time on the return train.

The advantage of these representations has to do with the synthetic nature of the indicator obtained: in a single number we can represent a duration of useful time, which is obviously fundamental for organising the programme of activities at destination and which certainly constitutes a pertinent indicator of the need to change the schedule. For example, the value of this indicator, as shown in Figure 1, is 4 hours and 48 minutes with the current Bordeaux-Paris schedules for a traveller who does not wish to leave before 8 a.m. and who wants to return before 7 p.m. This useful time would increase to 6 hours and 38 minutes at the running speeds authorised for the LGV, and with the same departure and arrival times.

This type of indicator offers a good explanation of certain observations concerning traveller demand following the introduction of a high-speed train service. In the first French case, that of the Paris-Lyon LGV introduced in the 1980s, traffic exceeded forecast demand, and the principal explanation had to do with the fact that the travel time, which was reduced from nearly 4 hours to 2 hours, and the high 
frequency of service allowed for many more same-day roundtrips, and even half-day trips, in place of longer stays and overnights at destination. This confirmed that there was a strong social demand, in particular from business travellers (Buisson et al., 2006) for this "available time at destination (ATD)".

Given the interest already declared by local stakeholders in this observatory and in monitoring the offer of transportation, it remains for them to express the types of ATD that should be promoted. It is clear that for each city the maximum ATD in Paris is of interest (as can be seen from Figure 1, it is 10 hours and 46 minutes with the current train schedules from Bordeaux, if one takes the first train in the morning and returns on the last at night). An ATD with more convenient schedules, such as those we have imagined above, should certainly be posted as well as an ATD for a half-day round trip.

Figure 1. Available time at destination (Paris), with a departure constraint (after 8 a.m.) and a return constraint (before 7 p.m.)

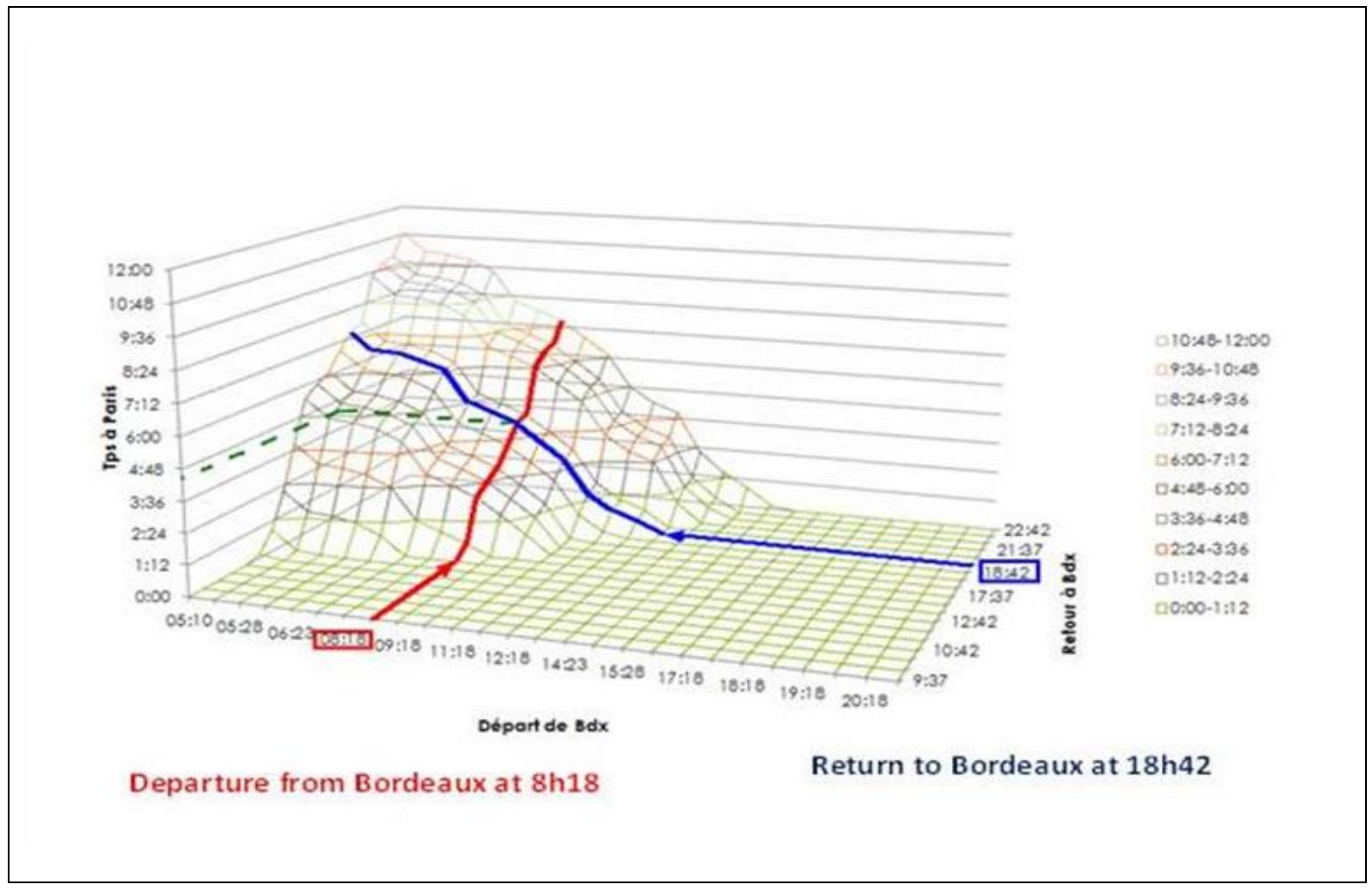

Source: Paul Joho (2013).

Of course, the observatory will have to establish these indicators for all LGV stations and for destinations other than Paris, which are yet to be determined, as well as for stations which are not on the high-speed line but which benefit from the TGV services using that line (for example La Rochelle, Toulouse). Where airline service exists, the schedules should be the subject of comparable treatment and posting. This assumes that it is possible to evaluate transportation time to the terminals, as well as the advance check-in or arrival times that passengers must observe for each mode.

With respect to the short life of information, the other main methodological challenge, the best illustration is no doubt that concerning fares. The fact that airline and TGV operators practice "yield 
management" makes the problem especially complex. Information is available on the minimum and maximum values of these fares for a second-class TGV ticket, because SNCF is legally obligated in its operating specifications to publish it. A recent version of the official text added the following sentences: "SNCF shall publish and communicate clearly and fully the lowest fare, apart from promotional fares, and the highest fare for a second-class ticket applicable for each route. This fare information shall be made readily accessible to users of the route." Airlines are not under the same constraint.

However, a close examination of actual rail fares suggests that this obligation to publish is a weak constraint and not very helpful for a real understanding of fares. Figure 2 below, taken from studies by Paul Joho (2013), provides persuasive evidence on this point. It shows that, for a given departure date on the Bordeaux-Paris trains, the minimum price rises almost daily according to the time elapsed since the reservation was made.

We can distinguish the particular case of a single train for which the minimum fare is constant and fixed at EUR 90. This is a train leaving Bordeaux at 6:23 a.m. (which can also be identified in Figure 1) for which yield management does not apply, probably because it must run as nearly full as possible. For other trades, there is both a sharp chronological series variance (depending on time since reservation) and a sharp cross-series variance (depending on the train).

The problem of short-lived information is a glaring one: for a departure on 11 June, as shown in Figure 2, the fares posted at the ticket reservation sites on 22 May are no longer available on 23 May, and there is no chance that the carrier will be willing to offer them, unless forced to do so by competition from airlines or, within a few years, from other rail operators. The only solution, then, is to conduct a systematic and comparative survey of reservation sites.

A systematic survey will require selecting trains in such a way as to replicate the diversity of origins-destinations as well as of travel days (weekdays, weekend, major vacation periods). It also means distinguishing the profiles of buyers and the type of ticket they choose (second-class ticket with a senior card; exchangeable second-class ticket; first-class ticket etc.). Lastly, for a given departure date, different advance reservation times must be set (for example, 3 months, 1 month, 7 days and previous day). A similar exercise will have to be undertaken for airline connections.

A thorough survey of this kind will require compiling and working with thousands of fares, and consequently thought should be given to using synthetic indicators. When the LOTI audits mention rail fare increases or airfare cuts, they give no indication of the orders of magnitude. The audits should be improved in this regard, not only to provide useful information to stakeholders but also to be able to explain eventual errors in traffic or revenue forecasts. The observatory is now examining the question of synthetic indicators for fares. 
Figure 2. Minimum fare for all Bordeaux-Paris trains, based on length of time elapsed since reservation to departure date

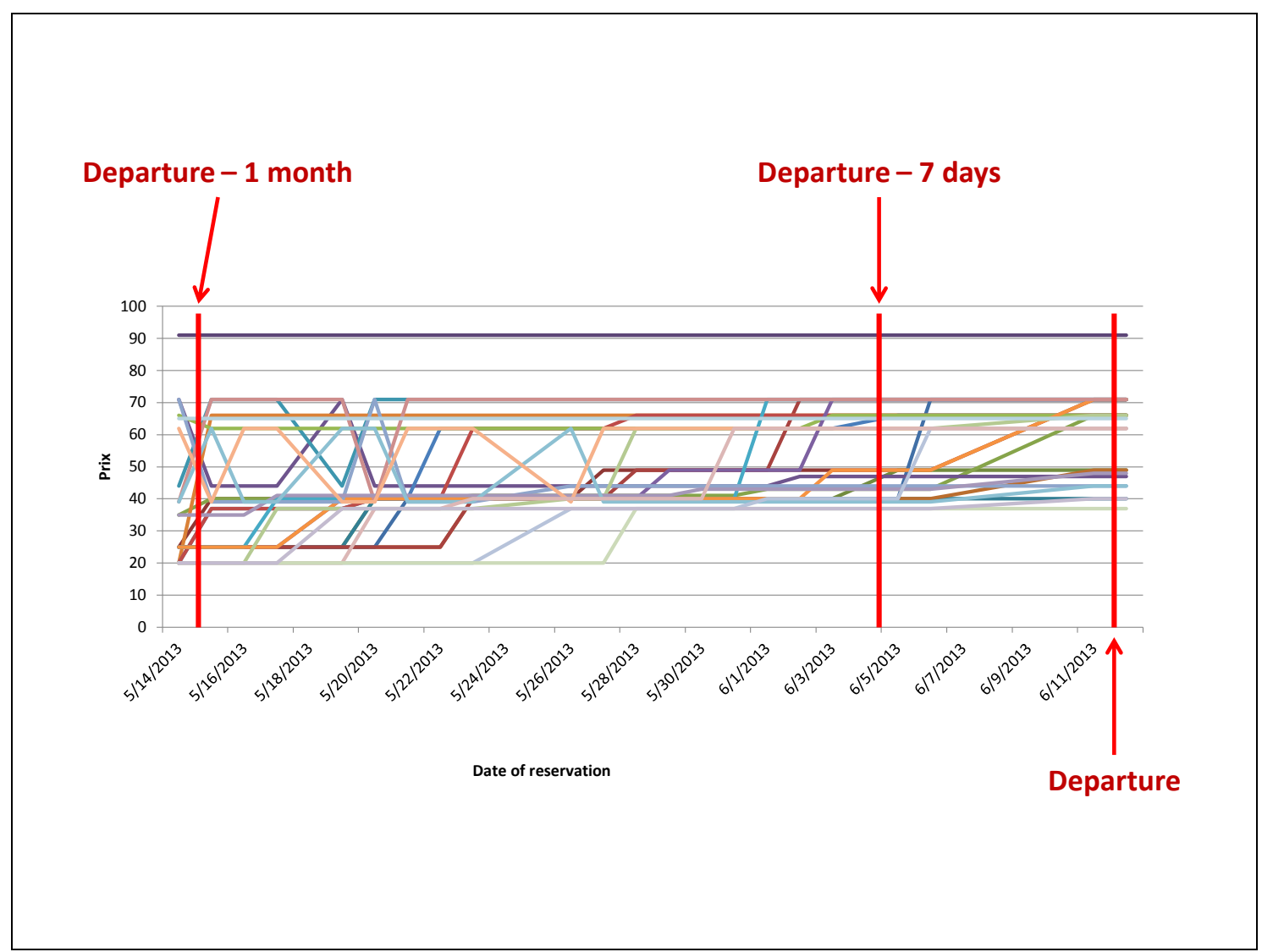

[Left-hand axis: Time in Paris]

Source: Paul Joho (2013). 


\section{Conclusion: Addressing the Challenges of Complex and Short-lived Data}

Between the launch of the SPOT discussed in section 3, the first permanent observatory of a new infrastructure project introduced at the end of the 1970s, and the OSE-LISEA, established just two years ago, more than three decades have elapsed and yet there has been an obvious methodological continuity. In fact, for all these French experiments, the challenge has been to find a dual response: on one hand, to address the volume of information gathered (remembering that information overload is lethal), and on the other hand to address the well-known erosion and even disappearance of information. One may be tempted to gather ever more information, recognising that it is likely to disappear soon, and this makes for a massive and unwieldy database, as illustrated in the last example cited here.

However, besides its longevity, the socioeconomic observatory for the LGV South-Europe-Atlantic has the particular advantage of offering answers to these problems: the involvement of multiple local partners can help to appreciate the pertinence of synthetic indicators and thus assist in choosing those that will be useful for enlightening public debate. This choice, of course, must be made with knowledge of the uses to which the data will be put, particularly for the most technical aspects - for example, analysing the quality of forecasts on which the investment decision is based. The primary goal of the ex-post evaluation will always be to help prepare better ex-ante evaluations. 


\section{Annex 1}

\section{List of "Bilans LOTI" [LOTI audits]}

21 August 2013

- LGV Est européenne (phase 1)

Avis [Opinion] no_009145-01 (format pdf - 1 MB) - July 2013

- Construction of Autoroute A 28 Alençon-Tours

Avis $\underline{n^{\circ} 008517-01}$ (format pdf - 940.1 KB) - February 2013

- Aeronautical infrastructure upgrade at Paris-Charles de Gaulle Airport

Avis $\underline{\mathrm{n}^{\circ} 008039-01}$ (format pdf - 1.5 MB) - July 2012

- Electrification of the Rennes - Saint-Malo line

Avis $\underline{\mathrm{n}}^{\circ}$ 007847-01 (format pdf - 1.1 MB) - July 2011

- Autoroute A83 Nantes - Niort

Avis $\underline{n^{\circ} 007538-01}$ (format pdf - 1.5 MB) - June 2011

- Autoroute A 20 (Section Brive Montauban)

Avis $\underline{\mathrm{n}^{\circ} 007284-01}$ (format pdf - 1.3 MB) - April 2011

- Operation of tramway $\mathrm{T2}$

Avis $\underline{n^{\circ} 007715-01}$ (format pdf - 964.8 KB) - May 2011

- Autoroute A75 Engayresque-La Cavalerie south section, including the Millau viaduct Avis $\underline{n}^{\circ}$ 007191-01 (format pdf - 460.6 KB) - February 2011

- Autoroute A66 (bifurcation A61 - Pamiers)

Avis $\underline{\mathrm{n}^{\circ} 007283-01}$ (format pdf - $480.9 \mathrm{~KB}$ ) - November 2010

- Re-routing of the RN 12 to Jouars - Pontchartrain

Avis $\mathrm{n}^{\circ} 007447-01$ (format pdf - 493.5 KB) - November 2010

- A16: concessioned section: L'Isle-Adam - Amiens - Boulogne and A16: nonconcessioned section: Boulogne - Belgian border

Avis $\underline{n^{\circ} 007087-01}$ (format pdf - 1.2 MB) - July 2010

- A75 Clermont-Ferrand - Sévérac-le-Château

Avis $\underline{n^{\circ} 006652-01}$ (format pdf - 776.1 KB) - April 2010

- Electrification of the Paris - Clermont-Ferrand rail line 
Rapport $\underline{\mathrm{n}^{\circ} 007156-01}$ (format pdf - 455.9 KB) - January 2010

- Autoroute A26 Châlons-en-Champagne - Troyes

Avis $\underline{n^{\circ} 003820-02}$ (format pdf - 628.6 KB) - December 2009

- Autoroute A51 Sisteron-La Saulce

Avis $\mathrm{n}^{\circ}$ 006654-01 (format pdf - 526.6 KB) - November 2009

- Autoroute A29, Pont de Normandie-A13 and Le Havre-Saint-Saens sections and the Pont de Normandie

Avis $\underline{n^{\circ} 006600-01}$ (format pdf - 914.5 KB) - October 2009

- Electrification of the Paris - Caen - Cherbourg rail line and upgrade of the Paris Granville rail line

Avis CGEDD - $\underline{\mathrm{n}^{\circ} 006948-01}$ et ${ }^{\circ}$ 006949-01 (format pdf - 631.4 KB) - September 2009

- Autoroute A5 La Francilienne - Troyes

Avis CGEDD $\underline{n^{\circ} 005616-01}$ (format pdf - $801 \mathrm{~KB}$ ) - January 2009

- Electrification of rail lines in Bretagne

Avis CGEDD n $^{\circ}$ 05921-01 (format pdf - 448.4 KB) - July 2008

- Autoroute A 39 - Sections Dijon - Dôle and Dôle - Bourg-en-Bresse

Avis CGPC $\underline{n^{\circ} 005322-01}$ (format pdf - 682.1 KB) - July 2008

- Autoroute A 19 - Section Sens - Courtenay

Avis CGPC $\underline{n^{\circ} 005138-01}$ (format pdf - 2.2 MB) - July 2008

- LGV Rhône-Alpes et Méditerranée

Rapport [Report] CGEDD n ${ }^{\circ}$ 005448-01 (format pdf - 1.1 MB)

Avis délibéré du CGEDD n005448-01 (format pdf - 848.6 KB) - July 2008

- CGPC opinion on the bilan LOTI of Autoroute A 77 - Section Dordives - Cosne-surLoire

Avis CGPC n ${ }^{\circ} 005781-01$ (format pdf $-634.5 \mathrm{~KB}$ ) - June 2008

- CGPC opinion on the bilan LOTI of train speed control by tracking antenna (KVB) Avis CGPC $\underline{n}^{\circ}$ 005721-01 (format pdf - 596.1 KB) - March 2008

- Autoroute A54 (Saint-Martin-de-Crau - Salon-de-Provence)

n ${ }^{\circ}$ 005295-01 (format pdf - 565 KB) - December 2007

- Puymorens Tunnel

Avis CGPC nº05172-01 (format pdf - 296.7 KB) - December 2007

- RER stations at Stade de France

Bilan LOTI RER Stade de France (format pdf - 1.9 MB) - RFF - November 2006

Avis CGPC $\underline{n^{\circ} 005438-01}$ (format pdf - 504.2 KB) - August 2007

- Autoroute A837 (Saintes-Rochefort) 
Concessionnaire ASF

$\underline{\mathrm{n}^{\circ} 5173-01}$ / Avis du CGPC : A837 (format pdf - 525.5 KB) - July 2007

- RER D (Gare de Lyon-Châtelet connection), RER E (Eole) and metro line 14 (Météor)

Bilan LOTI interconnexion du RER D Châtelet-gare de Lyon (format pdf - 1.3 MB) - RFF March 2006

Bilan LOTI RER E (format pdf - 2.3 MB) - RFF - mars 2006

Avis CGPC $\underline{\text { n } 004956-01}$ (format pdf - 129.1 KB) - June 2007

- Non-concessioned Autoroute A28 (Rouen-Abbeville)

DRE Haute-Normandie et Picardie

Le rapport relatif à l'A28 (format pdf $-6 \mathrm{MB}$ )

$\underline{n^{\circ} 004891-01}$ / L'avis du CGPC : A28 (format pdf - 484.4 KB) - February 2007

- Non-concessioned Autoroute A20 (Vierzon-Brive)

Direction Régionale de l'Équipement du Limousin

Le rapport et ses annexes $(1,2,3)$ (format pdf $-1.7 \mathrm{MB}$ )

$\underline{\mathrm{n}^{\circ} 004812-01}$ / L'avis du CGPC : A20 (format pdf - 485.4 KB) - February 2007

\section{- RN 24}

Direction Régionale de l'Équipement de la Bretagne

$\underline{\mathrm{n}^{\circ} 004813-01}$ / L'avis du CGPC : RN24 (format pdf - 379.6 KB) - January 2007

\section{- LGV Nord Europe et Ile-de-France Interconnection}

Bilan LOTI LGV Nord (format pdf - 806.7 KB) - RFF - May 2005

Bilan LOTI Interconnexion Ile-de-France (format pdf - 2.1 MB) - RFF - September 2005

Avis CGPC $\underline{n^{\circ} 004624-01}$ (format pdf - 648.7 KB) - July 2006

\section{- Autoroute A14 (Orgeval-Nanterre)}

Concessionnaire SAPN

L'avis du CGPC : A14 (format pdf - 181.2 KB) - November 2005

La brochure de présentation de SAPN (format pdf - 1.1 MB)

\section{- Autoroute A57 (Cuers/Le-Cannet-des-Maures)}

Concessionnaire ESCOTA

n 2004-0263-01 / L'avis du CGPC: A57 (format pdf - 67.6 KB) - December 2004

- Tramway line between Saint-Denis and Bobigny (93)

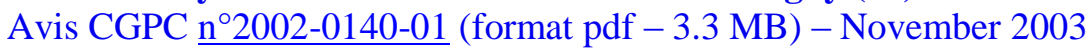

- TGV atlantique

Avis CGPC $\underline{n^{\circ} 1999-0163-01}$ (format pdf - 374.2 KB) - July 2001

- Upgrade of the Montmélian-Albertville-Moûtiers link

Concessionnaire AREA

L'avis du CGPC : A43 (format pdf - 3.1 MB) - November 1999

- Autoroute A49 (Grenoble-Valence)

Concessionnaire AREA

L'avis du CGPC : A49 (format pdf - 1.4 MB) - November 1999 
Annex 2

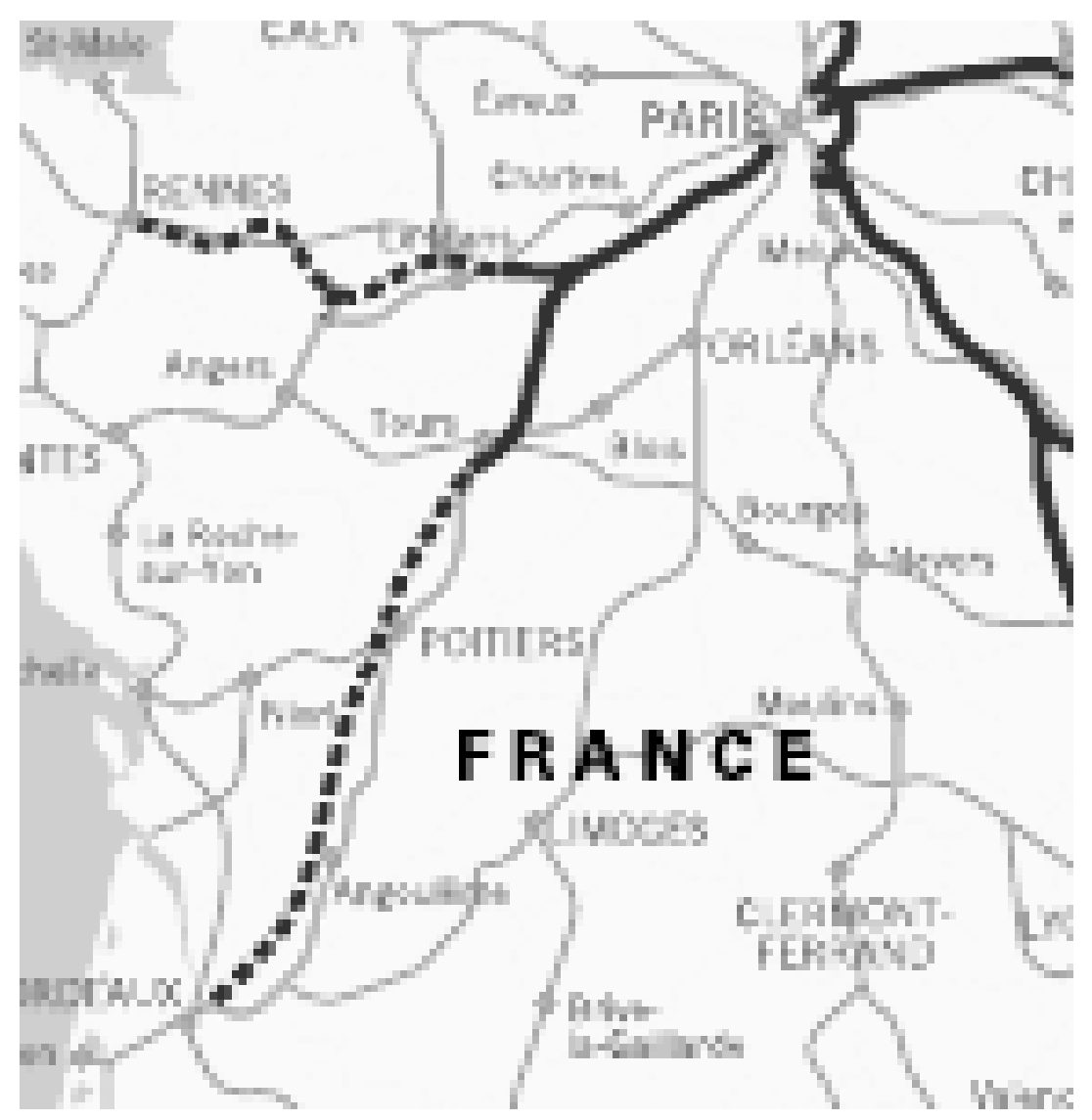

Source : Réseau Ferré de France. 


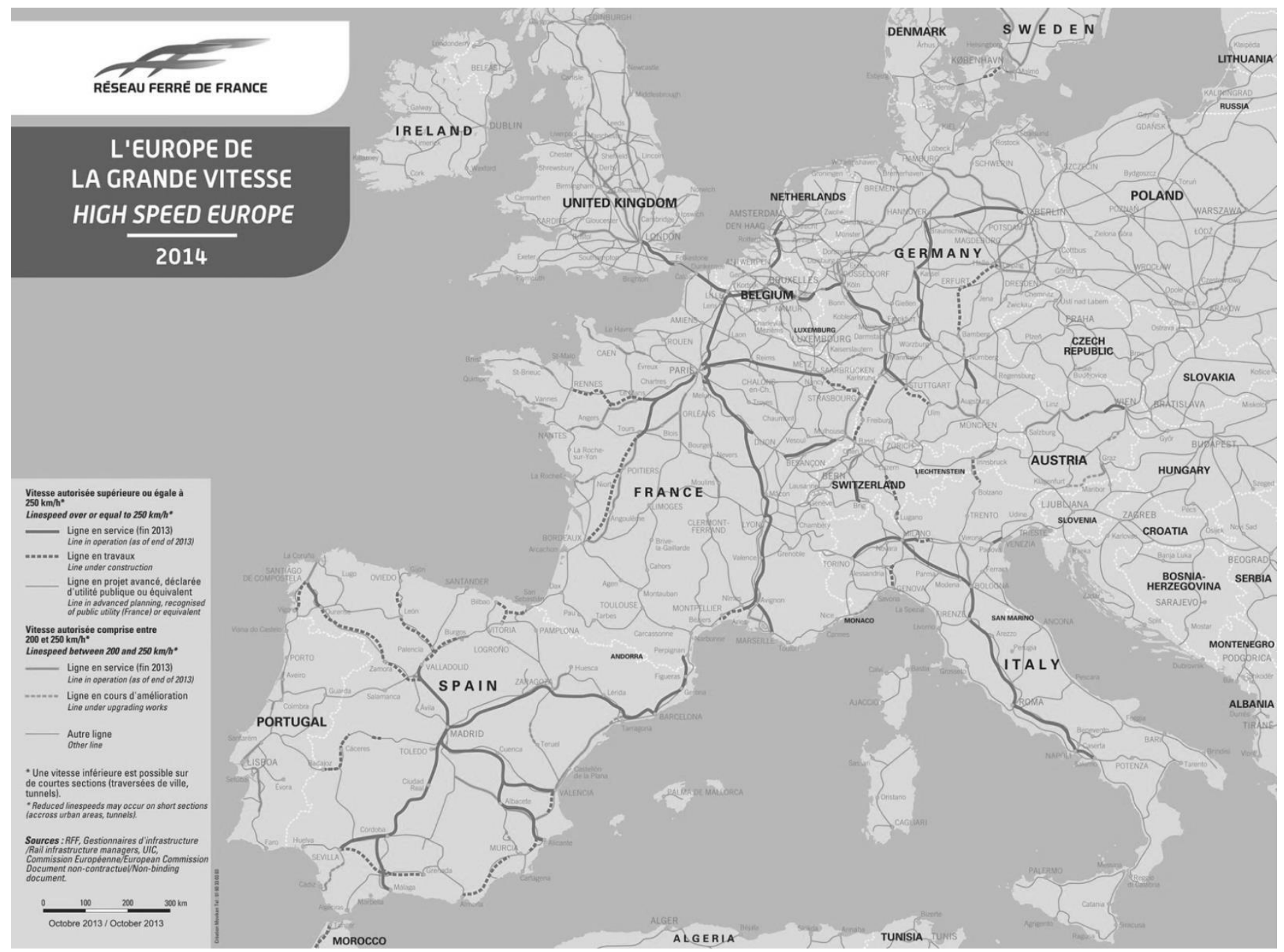

Source : Réseau Ferré de France. 


\section{Annex 3}

\begin{tabular}{|l|c|c|}
\hline \multicolumn{3}{|c|}{ Travel times: table comparing current line / LGV SEA line } \\
\hline \multicolumn{1}{|c|}{ Routes } & $\mathbf{2 0 0 7}$ & $\mathbf{2 0 1 7}$ \\
\hline Paris - Poitiers & $1 \mathrm{~h} 26$ & $1 \mathrm{~h} 17$ \\
\hline Paris - Angoulême & $2 \mathrm{~h} 05$ & $1 \mathrm{~h} 40$ \\
\hline Paris - Bordeaux & $3 \mathrm{~h} 00$ & $2 \mathrm{~h} 05$ \\
\hline Paris - La Rochelle & $2 \mathrm{~h} 50$ & $2 \mathrm{~h} 27$ \\
\hline Bordeaux - Tours & $2 \mathrm{~h} 30$ & $1 \mathrm{~h} 30$ \\
\hline Bordeaux - Angoulême & $0 \mathrm{~h} 52$ & $0 \mathrm{~h} 35$ \\
\hline Poitiers - Bordeaux & $1 \mathrm{~h} 32$ & $0 \mathrm{~h} 55$ \\
\hline Poitiers - Angoulême & $0 \mathrm{~h} 44$ & $0 \mathrm{~h} 37$ \\
\hline Poitiers - Tours & $0 \mathrm{~h} 47$ & $0 \mathrm{~h} 30$ \\
\hline Tours - Angoulême & $1 \mathrm{~h} 32$ & $1 \mathrm{~h} 07$ \\
\hline Paris - Toulouse & $4 \mathrm{~h} 56$ & $4 \mathrm{~h} 03$ \\
\hline
\end{tabular}

Sources: SNCF and RFF 2007 - Average indicative travel times. 


\section{Bibliography}

Bazin, S., C. Beckerich and M. Delaplace (2009), Desserte TGV et localisation des entreprises dans les quartiers d'affaire: nouvelle accessibilité ou nouvelle offre de bureau? Le cas de la gare centre de Reims, Les Cahiers scientifiques du transport (56).

Bérion, P. (1995), L'Observatoire de l'autoroute A39: démarche utilisée et présentation de l'état initial, Autoroutes, économie et territoires, CERAMAC, Clermont-Ferrand, 1998, pp. 123-137.

Bérion, P., G. Joignaux and J.F. Langumier (2007), "L'évaluation socio-économique des infrastructures de transport: Enrichir les approches du développement territorial", Revue d'Économie Régionale \& Urbaine, No. 4, pp. 651-676. (DOI: 10.3917/reru.074.0651)

Bonnafous, A. (1979), Underdeveloped regions and structural aspects of transport infrastructure, in: W.A. Blonk (Ed.), Transport and Regional Development, Saxon House, Farnborough, pp. 45-62.

Bonnafous, A. (1980), Rhône-Alpes, capitale Paris: les effets prévisibles du TGV, Revue de géographie de Lyon, No. 3. (http://www.youscribe.com/catalogue/presse-etrevues/savoirs/sciences-humaines-et-sociales/rhone-alpes-capitale-paris-les-effets-previsiblesdu-t-g-v-1082747)

Buisson, M.A., A. Bonnafous, J.L. Bernadet, C. Jafflin and D. Mignot (1986), Effets indirects du TGV et transformations du tertiaire supérieur en Rhône-Alpes, Études et recherches, Laboratoire d'Economie des Transports. (http://hal.archivesouvertes.fr/docs/00/81/83/15/PDF/EFFETS INDIRECTS DU TGV.pdf)

ECMT (1975), Round Table No. 4, The impact of Infrastructural Investment on Economic Development, OECD Publications.

ECMT (1969), Round Table No. 25, Impact of Infrastructural Investment on Industrial Development, OECD Publications.

Fouqueray, E. (2013), Sous-traitance et fourniture du chantier de la LGV SEA Tours-Bordeaux : quelles retombées pour les territoires?, Observatoire Socio-économique LISEA. (http://www.lgv-sea-tours-bordeaux.fr/engagements-durables/observatoire-socio-economiquelisea)

Gérardin, B., J.-M. Cusset, A. Bonnafous and J. Valère (1981), Système permanent d'observation du triangle Lyon-Chambéry-Grenoble (Spot), 237 pp. (http://www.let.fr/). 
Joho, P. (2013), Suivi de l'évolution de l'offre de transport liée à l'arrivée de la LGV SEA Tours-Bordeaux dans le cadre de l'Observatoire socio-économique mis en place par LISEA, Observatoire Socio-économique LISEA. (http://www.lgv-sea-tours-bordeaux.fr/engagementsdurables/observatoire-socio-economique-lisea)

Manceau, E. (2012), "La ligne grande vitesse Tours-Bordeaux et ses effets vus par les acteurs du territoire", Observatoire Socio-économique LISEA. (http://www.lgv-sea-toursbordeaux.fr/engagements-durables/observatoire-socio-economique-lisea)

Manceau, E. (2013), "Programme de travail de l’Observatoire socio-économique 2013-2020", Observatoire Socio-économique LISEA. (http://www.lgv-sea-tours-bordeaux.fr/engagementsdurables/observatoire-socio-economique-lisea)

Ministère de l'écologie du développement durable et de l'énergie (2014), Bilans LOTI. (http://www.developpement-durable.gouv.fr/Bilans-LOTI.html )

Plassard, F. (1977), Les autoroutes et le développement régional, Economica, 342 pp, Paris.

Richer, C., P. Bérion and V. Facchinetti-Mannone (2009), L'observatoire des effets territoriaux des gares du TGV Rhin-Rhône : contexte, enjeux et perspectives, Images de Franche-Comté, (40), $2-5$.

UIC (2011), High Speed Rail as a tool for regional development, In-depth Study, (http://www.uic.org/download.php/publication/533E.pdf)

Varlet, J. and C. Jamot (2002), "Autoroute A71, acteurs et territoires. Bilan d'une décennie d'observations", Géocarrefour, Vol. 77, No. 1.

(http://www.persee.fr/web/revues/home/prescript/article/geoca_16274873_2002_num_77_1_6259). 
